\title{
KARAVANKE - OD LOČNICE DO STIČIŠČA SLOVENCEV Z OBEH STRANI MEJE
}

\author{
Jernej Zupančič
}

Izvleček

UDK 341.222(234.3 Karavanke)

Prispevek obravnava družbenopolitični razvoj območja Karavank, kjer so se v zgodovini menjavala ločevalna in povezovalna obdobja, še posebej za Slovence, živeče na obeh straneh meje. Potem ko je območje v 19. stoletju postalo stičišče, ga je nova meja po prvi svetovni vojni postavila $v$ vlogo ločnice. Ločitev nikoli ni bila popolna in prav potrebe krajevnega prebivalstva so narekovale vedno večje odpiranje meje in oblikovanje čezmejnih tokov. Karavanke so ponovno postale stičišče Slovencev z obeh strani meje ter prehodna pokrajina za mednarodne tokove.

ključne besede: meja, čezmejni odnosi, Koroška, Slovenci, manjšine, Karavanke, Alpe

\author{
THE KARAVANKE RANGE - FROM ITS DIVIDING TO THE UNITING ROLE BETWEEN \\ THE SLOVENIANS ON BOTH SIDES OF THE BORDER
}

\section{Abstract}

Paper deals on socio-political development of Karavanke mountains, which had changing the division- and conecting role in historical development, especialy for slovene population, living on both sides of border. This mountain barriere became in 19.th century conecting area for Slovenes of Carniola and Carinthia. After World War I., Karavanke became a border zone with strong division- function. Even though, the local population of both sides found some posibilities to comunicate with each other, what finnaly led to the today" s larger transborder cooperation. In frame of this, slovene minority in Carinthia has a visible role and function.

Key words: border, transborder relations, Carinthia, Slovenes, minorities

\footnotetext{
${ }^{*}$ Dr., Inštitut za geografijo, Trg francoske revolucije 7, 1000 Ljubljana, Slovenija
} 


\section{UVOD}

Pokrajinska pestrost slovenskega alpskega sveta je v slovenski ljudski kulturi sredotežen pojem. Radi se imenujemo alpski narod, Slovenijo pa alpska dežela. Alpski oziroma gorski svet nasploh ima v smislu prostorske identifikacije pomembno mesto v slovenski identiteti. Triglav, Bled, Planica in Soča so značilne slike, s katerimi se rad poistoveti malodane sleherni Slovenec v deželi na sončni strani Alp. Zaradi tega je pojem alpskega sveta $\mathrm{v}$ miselnem, pogosto mitološko obarvanem svetu Slovencev pomenil povezovalno prvino ne glede na regionalno pripadnost. Shematični prikaz Triglava nas že skoraj stoletje spremlja kot prepoznaven narodni in državni simbol. Slednjič je treba podčrtati velik prometni in gospodarski pomen Alp za slovensko državo.

Karavanke, del slovenskega alpskega sveta, so se v predstavah uveljavile kot ločnica. Našo pozornost vzbujajo že zaradi svoje dolžine, saj potekajo sklenjeno več kot 80 km dolgo. Prvi slovenski državi Karantaniji so pomenile naravno južno mejo. Stoletja dolgo so na njih vztrajale deželne meje, po usodnem razpletu po prvi svetovni vojni pa so postale severna meja slovenske banovine, kasneje republike in države. Globalne politične spremembe $v$ Evropi na eni ter potrebe prebivalcev Karavank in sosedstva narekujejo preseganje starih pregraj: fizičnih, političnih in miselnih. Meje v Evropi dobivajo novo vlogo in novo podobo. Tudi območje Karavank ima v splošnih evropskih povezovalnih težnjah dobre možnosti, da $\mathrm{s}$ krepitvijo čezmejnega sodelovanja preseže včerajšnje spore ter se uveljavi kot novo povezovališče. Skrb in težnjo po povezovanju lepo simbolizira skupna kandidatura pokrajin ob Tromeji za zimske olimpijske igre leta 2006.

V prispevku želimo osvetliti ločevalno in povezovalno vlogo Karavank za Slovence. Pri tem ne moremo mimo širšega konteksta slovenskega narodnega razvoja niti mimo zgodovine in njenih še danes očitnih sledov. Družbeni, politični in gospodarski procesi so $\mathrm{v}$ stoletjih ustvarjali današnjo pokrajinsko in prebivalstveno podobo obravnavanega gorskega sveta. Kritično se je treba ozreti v pretekli razvoj in iz njega razbrati temeljne razloge ločevanja in povezovanja, tako fizične, politične, gospodarske, družbene, kulturne, ideološke ter etnične. Zaradi omejenega prostora bo mogoče nekatere vidike zgolj na kratko omeniti, kajti glavna pozornost je vendarle usmerjena k današnjemu stanju ter razvojnim možnostim. 


\section{KARAVANKE - FIZIČNA LOČNICA ETNIČNO ENOTNEGA PROSTORA}

Stara fevdalna država Karantanija je bila v dobršni meri obdana z visokim naravnim zidom okoliških gora. Karavanke so bile njena južna meja, čeprav so tudi na južni strani živeli prebivalci podobnega jezika in kulture. Po propadu Karantanije so se uveljavile mejne grofije, v poznem srednjem veku pa so se izoblikovale dežele. Deželna meja med Kranjsko in Koroško se je ustalila na težko prehodnih Karavankah. Obe deželi sta bili del notranjeavstrijskih dežel z zelo podobno politično in upravno ureditvijo ter gospodarskim položajem (Zgodovina Slovencev, 1980). Upravna meja, naslonjena na fizično pregrajo, je ločevala dve območji z jezikovno in kulturno enotnim prebivalstvom. V tedanjih družbenih razmerah o narodu še ne moremo govoriti. To povezanost je še okrepila zadnja - višinska kolonizacija, ki je zaradi naravnih okoliščin v Karavankah obsegala precej obširna območja (Božič, 1980). Še danes sodijo Karavanke tudi $\mathrm{v}$ evropskem merilu med gosteje naseljene gorske predele. Značilnosti te kolonizacije so se $\mathrm{z}$ nekaj spremembami ohranile vse do danes. Izpričujejo jo razpršena poselitev v obliki manjših zaselkov in samotnih kmetij, kot so v območju Slovenj Plajberka, Sel, Obirskega in Železne Kaple na avstrijskem Koroškem ter v dolini Meže v Sloveniji. Območje obdelanega in (vsaj občasno) naseljenega sveta se je kasneje še dodatno ražsirjalo z gorskim pašništvom, gozdarstvom in oglarstvom. V krajih, kot so Slovenji Plajberk, Železna Kapla, Bela, Mežica, Črna in Javorniki, je izkoriščanje železove ter svinčeve in cinkove rude ustvarjalo razmere za gostejšo naselitev. V gospodarskem oziru je bila gorska veriga Karavank torej pomembno stičišče in povezovališče, ki je nase vezalo dejavnosti in prebivalce dolinskih naselij na severni in južni strani.

Visoka in dolga gorska veriga je pomenila znatno oviro za promet, ki se je moral valiti čez visoke prevale: Korensko, Ljubeljsko in Jezersko sedlo. Pozimi so bili večinoma neprehodni. Od vseh prometnih poti čez Karavanke so največ uporabljali tisto prek Ljubelja, deloma zaradi bolj zložnega prehoda, predvsem pa zaradi najkrajše razdalje med Ljubljano oziroma Kranjem ter Celovcem in Šentvidom. Ob vznožju sta se razvila Tržič na južni in Borovlje na severni strani. Živahnost stikov dokazujejo tudi nekateri zgodovinski dogodki, kot so npr. kmečki upori. Jezikovna enotnost je čezmejne stike vsekakor pospeševala (Zgodovina Slovencev, 1980).

Enotnost v jezikovno-kulturnem smislu je vodila $v$ vedno večjo povezanost ljudi na severni in južni strani Karavank, dokler se ni v obdobju pomladi narodov v 18. in predvsem v 19. stoletju dokončno oblikoval v slovenski narod. Slovensko narodno gibanje se je izražalo zlasti na kulturnem in jezikovnem, kasneje pa vedno bolj tudi na gospodarskem in političnem področju. Organizirali so tabore in čitalnice ne glede na takratne deželne meje. Vrsta kulturnih in političnih delavcev tiste dobe je izvirala $\mathbf{s}$ Koroške. Celovec je bil eno najpomembnejših in najbolj vitalnih slovenskih kulturnih žarišč. Dvig izobrazbene ravni in vedno večja narodna ozaveščenost je premagala krajevne in deželne okvire ter ustvarjala pogoje za politično manifestacijo, ki se je 
pred 150 leti uresničila s programom "Zedinjene Slovenije". Karavanke so bile prometna ovira, nikakor pa ne miselna ločnica Slovencev Koroške, Štajerske in Kranjske. Zaradi narodne enotnosti so bile v vedno večji meri povezovališče, obenem pa tudi enoten gospodarski prostor. Tradicija starega rudarstva v omenjenih območjih Karavank je sicer že vidno pojemala. Namesto nje se je uveljavila modernejša železarska, kovinskopredelovalna, strojna in tekstilna industrija ter obrt na Jesenicah, v Podkloštru, Tržiču, Borovljah in Ravnah (tedaj Guštanju). Po dolini Drave je stekla železnica in skozi predor povezala Dravsko in Savsko dolino ter širše območje ob njih. Območje Karavank je bilo tedaj na višku agrarne naseljenosti (Zupančič, 1992).

\section{FIZIČNA LOČNICA POSTANE ARGUMENT POLITIČNE RAZMEJITVE}

Tesna povezanost slovenstva ter njihov politični nastop skupaj $\mathrm{z}$ narodnim preporodom drugih narodov Habsburške monarhije je povzročala vedno večje spore $z$ državnim - nemškim nacionalizmom. Asimilacija je zlasti na Koroškem dobila značaj in vlogo državne ideologije. $\mathrm{V}$ zaostrenem ozračju napetih medetničnih odnosov je monarhija sprožila prvo svetovno vojno. Vojaškemu porazu v njej je sledil razpad države po etničnih šivih. Oblikovalo se je več nacionalnih držav, ki so skušale pester etnični zemljevid pridobljenih ozemelj $\mathrm{v}$ čim krajšem času poenotiti, pogosto $\mathrm{z}$ nasilnimi asimilacijskimi ukrepi (Taylor, 1956; Zwitter in sod., 1962).

Ob določevanju novih meja je prišlo do vojaških spopadov in slovenska severna meja na Karavankah je postala predmet mednarodne diplomatske obravnave na mirovni konferenci v Parizu. Med argumenti na diplomatski mizi se je znašel tudi pojem naravne meje, v našem primeru Karavanke. Zahodni diplomati so zagovarjali mejo po gorski pregraji, češ da le-ta najbolj zaokroža enoten gospodarski prostor in da je ta argument pomembnejši od narodnostnega načela (Barker, 1984). Kasneje so uporabili instrument plebiscita, ki je razen Jezerskega, Mežiške doline in Kanalske doline pustil Koroško v avstrijskem okviru. 10. oktobra 1920 so Karavanke postale za Slovence ločnica (Randall, 1954). Koroški Slovenci so postali narodna manjšina. Z nastankom politične meje se je pričel ločeni narodni, kulturni, politični, prostorski in gospodarski razvoj manjšine in t. i. matičnega naroda. V dobrih sedmih desetletjih so se razlike povečevale, nakopičile pa so se tudi miselne pregraje ideoloških in kulturnih razsežnosti. Te kot uveljavljeni miselni vzorci, strahovi in predsodki pomembno krojijo življenje prebivalcev krajev in območij ob tromeji.

Ločen razvoj se najprej kaže v etničnem razvoju. Slovenci na avstrijskem Koroškem so se razvijali kot manjšina, torej $\mathrm{z}$ zelo omejenimi možnostmi razvoja lastnih kulturnih in izobraževalnih ustanov ter omejenimi stiki s Slovenijo. Krepki asimilacijski pritiski so močno načeli številčnost skupnosti, ki se je v slabih sto letih močno zmanjšala tako po uradnih podatkih kot po ocenah (Zupančič, 1996). Omejen 
je bil tudi gospodarski razvoj območij ob meji, saj so bile presekane nekatere tradicionalne vezi preko Karavank.

V sklop asimilacijskih prizadevanj sodijo tudi poskusi etnične odtujitve. Prvi primer je uvedba kategorije "vindišarjev". Izraz "vindiš" je bil nekoč nemški izraz za Slovenca. Šele po plebiscitu je pričel dobivati povsem novo vsebino. Ta se je večkrat spreminjala in enkrat označevala »jezikovno mešanico«, drugič »domovini zveste Slovence«, tretjič posebno skupnost s koroško deželno zavestjo, če se omejimo le na najpogosteje uporabljane variante (Klemenčič, 1990; Zupančič, 1996, po Zorn, 1974). Druga oblika poskusa spreminjanja etnične podobe slovenskega prebivalstva na Koroškem je bilo poudarjanje vloge regionalne oziroma deželne zavesti, ki jo nekateri avtorji postavljajo celo namesto narodne. Po tej hipotezi naj bi bili vsi prebivalci »Korošci«, ki se razlikujejo le po jeziku na nemško- in slovensko govoreče (Zupančič, 1997). To bi držalo le v primeru, če bi bila deželna identiteta tako močna le na Koroškem, ne pa tudi $\mathrm{v}$ drugih avstrijskih deželah ali predelih Slovenije. Regionalna identiteta je $\mathrm{v}$ teh območjih močno zasidrana in trajna. $\mathrm{Z}$ novejšimi terenskimi raziskavami smo ugotovili, da lokalne in regionalne (tudi deželne) identitete niso $\mathrm{v}$ nasprotju $\mathrm{z}$ narodno identiteto, temveč jo dopolnjujejo (Zupančič, 1996). Do narodne indiferentnosti prihaja veliko redkeje, kot se skuša to poudarjati. Navadno je omejeno na mešane družine ter na nekatera območja; pri slednjih je treba podrobno preučiti vzroke za tako stanje. Tudi na ravni Evropske zveze se krepijo regionalne identitete, a krepijo se tudi narodne - etnične. Neupravičena so pričakovanja, da bo krepitev regionalnih identitet premagala nacionalizem in etnično razdeljenost nastopajoče evropske družbe.

V obdobju nemške okupacije in vključitve večjega dela Slovenije v okvire Tretjega rajha je politična meja na Karavankah za nekaj let spet postala zgolj administrativna. Karavanke so postale zaradi obsežnega gorskega in gozdnatega sveta zatočišče odporniškega partizanskega gibanja, hkrati pa ponovno spet povezovališče, za kratek čas spomladi leta 1945, ko so južno Koroško osvojile partizanske čete, celo enoten prostor.

Po drugi svetovni vojni se je kljub naprezanju takratne jugoslovanske diplomacije, da bi dosegli spremembo meje, ponovno vzpostavila državna meja na Karavankah. Karavanke so zopet postale ločnica Slovencev: matice in manjšine (Zgodovina Slovencev, 1980). Družbenopolitični razvoj v povojni Jugoslaviji je ustvaril novo pregrajo na Karavankah: ideološko. Razlike med Slovenci to- in onstran Karavank so se pričele na več področjih naglo stopnjevati. V Sloveniji se je skladno z ideologijo brezrazredne družbe uveljavila paradigma industrijskega razvoja, ki je temeljil predvsem na razvoju težke (bazične) industrije. Železarstvo je imelo v tem prostoru sicer zgledno tradicijo, vendar ne najboljših lokacijskih pogojev. Pospešen razvoj industrije je zanemaril nekatere druge gospodarske panoge, kot so zlasti različne terciarne dejavnosti s trgovino in turizmom na čelu. Tako sta se $\mathrm{v}$ naravno razmeroma podobnih okoliščnah razvijala dva različna koncepta družbenogospodarskega in prostorskega razvoja. Medtem ko je Koroška s skromno industrializacijo razmeroma 
hitro pričela krepiti zlasti turizem in terciarizacijo nasploh, je na južni strani Karavank vedno več ljudi zaposlovala industrija.

Državna meja na Karavankah je bila skoraj dve desetletji precej zaprta. V šestedesetih letih se je pričela odpirati, vendar je $\mathrm{v}$ glavnem pomenila izhodna vrata za številne zdomce, ki so šli s trebuhom za kruhom v Avstrijo, Nemčijo, Švico in druge zahodnoevropske države. Gospodarska izmenjava je bila tedaj razmeroma skromna. Krepitev gospodarske moči pokrajin na južni strani Karavank ter siceršnja gospodarska usmeritev Slovenije proti Zahodu je Karavanke vedno bolj oblikovala v tranzitno območje. Velike količine blaga po železnici in turistični tokovi proti morju so bili značilen pojav sedemdesetih in še osemdesetih let.

Različna družbenopolitična in gospodarska ureditev ter njegova ideološka pogojenost sta poglabljale tudi razkol znotraj slovenske manjšine na Koroškem, hkrati pa povečevala razlike $\mathrm{v}$ vsebini identitete pripadnikov manjšine in matičnega naroda (zadnji izraz je danes že skoraj neustrezen). Poglabljanje razlik med »matico« in slovenskimi manjšinami v sosednjih državah je pripeljalo do stanja, ki so ga nekateri označili kot stanje dveh slovenskih kultur. Zato se postavlja vprašanje, ali je sploh še mogoče govoriti o t.i. skupnem slovenskem kulturnem prostoru.

Odgovor je vsekakor pritrdilen. Slovenska kultura je bila v obdobju oblikovanja slovenskega naroda najmočnejši povezujoči dejavnik. Koroška je bila pri tem povsem enakopravno udeležena. Kasnejše odtujitve so bolj miselni vzorec kot pa odraz stvarnih razmer. Podrobnejše raziskave na velikem vzorcu (približno 500 vprašanih; predvsem starši dijakov slovenskih srednjih šol na avstrijskem Koroškem) so dokazale, da so posamezni stiki ves čas obstajali, stvarnim in namišljenim razlikam navkljub. V opisanem vzorcu je imela dobra polovica prijateljske ali sorodstvene vezi z osebami iz Slovenije (Zupančič, 1996). Kasnejši dogodki in današnji razvoj ter težnje so najboljši dokaz, da je meja na Karavankah tudi v obdobju največje ločnice vendarle "dihala".

Posebej je treba omeniti skrb Slovenije za slovensko manjšino na avstrijskem Koroškem, ki je znala kljub znatnim ideološkim razlikam prisluhniti temeljnemu cilju - ohranjanju slovenstva - in temu ustrezno podrediti tudi ukrepe. Mednje sodi tudi uvedba nekaj mešanih podjetij, kot so npr. obrat lesne industrije v Žitari vasi, tovarna celuloze pri Železni Kapli ter Elanova tovarna športne opreme na Brnci. Ti obrati so zaposlovali domačo slovensko delovno silo, hkrati pa so se krepili tudi stiki na drugih področjih. Za slovenska podjetja je bila to hkrati dobra priložnost uveljavljanja na zahodnih trgih in promet $\mathrm{z}$ devizami. Žal so šla mešana podjetja v obdobju tranzicije večinoma $v$ stečaj. 


\section{KARAVANKE POSTAJAJO POVEZOVALIŠČE}

Odprte meje, pomembni prometni tokovi ter odprta vprašanja gospodarskega sodelovanja so narekovali nove, formalne stike na območju vzhodnih Alp, na stiku dveh ideoloških in treh gospodarskopolitičnih in vojaških ureditev. Gotovo ni naključje, da je delovna skupnost Alpe Jadran pričela nastajati prav na tem prostoru ter pospeševati medsebojne stike in krepiti gospodarsko, kasneje pa tudi kulturno izmenjavo. Skupnost prvotno štirih članic se je razrasla v obsežno zvezo, ki je obsegala zelo različne republike, dežele, province, županije in države alpskojadranskega in panonskega prostora.

Za razvoj čezmejnega sodelovanja je poleg načrtnih prizadevanj poskrbel sam razvoj dogodkov. Gospodarska in politična kriza v Jugoslaviji je ob razmeroma visokih dohodkih na eni ter slabih možnostih akumulacije zasebnega kapitala $\mathrm{v}$ bankah, zavarovalnicah, vrednostnih papirjih ter drugih gospodarnih naložbah na drugi strani $\mathrm{v}$ drugi polovici osemdesetih let pospešila odliv kapitala čez mejo. Meje so bile v tem obdobju že odprte, promet čez mejne prehode živahen in prebivalci seznanjeni $\mathrm{z}$ možnostmi naložb in nakupov. Domača trgovinska ponudba je bila skromna, premalo iznajdljiva, premalo privlačna, slabo organizirana in predvsem predraga. Ob tem je ugoden menjalni tečaj samo še pospešil pravo nakupovalno mrzlico (Zupančič, 1997). $\mathrm{V}$ poznih osemdesetih letih se je oblikoval velikanski tok nakupovalcev, ki so obmejne kraje dobesedno preplavili v valu nakupovalnega turizma. Nekateri kraji kot so npr. Pliberk ali Borovlje, so imeli nekajkrat preveliko ponudbo predmetov široke potrošnje (Wastl-Walter, 1991; Podlipnig, 1991). Skokovit porast trgovinskega prometa in nova vrsta kupcev sta koroške trgovce prisilila k večjemu upoštevanju naravnanosti na zahtev in pričakovanj slovenskega in jugoslovanskega kupca. Pri tem je strmo narasla uporaba slovenščine, ki je postala uporaben poslovni jezik (Steinicke, Zupančič, 1994).

Pri prodaji zahtevnejših in dražjih izdelkov, kot so npr. izdelki bele tehnike, sredstev zabavne elektronike, gospodarskih strojev in naprav, računalnikov ter avtomobilov, so v trgovinah potrebovali tudi ljudi, vešče obeh jezikov, poznavalce zakonov in predpisov, navad, kulture in mentalitete obeh narodov. Koroških Slovencev, usposobljenih za te naloge, je bilo premalo in sledile so priselitve (največ začasne) na Koroško. Opazno povečanje števila priseljenih je dobro opazno v podatkih statističnega popisa iz leta 1991 (Zupančič, 1996). Zaradi naraščajoče brezposelnosti v Sloveniji ustrezne delovne sile ni bilo težko najti. Iskali so jo zlasti med tehničnim izobraženstvom.

Prav tako perspektivni dejavnosti sta bili bančništvo in zavarovalništvo. Zaradi slabih varčevalnih možnosti, visoke inflacije in nezaupanja $v$ varnost naložb doma so se mnogi odločili za vlaganje $\mathrm{v}$ tujini. Posledica tega je bilo začasno zaposlovanje slovenskih državljanov pri avstrijskih zavarovalnicah in bankah, kjer so delali kot agenti. 
Odprta meja in posebne razmere tik pred velikimi političnimi spremembami v Evropi so povzročile izjemno dinamičen promet in obilico raznovrstnih stikov preko Karavank. Te so ponovno postajale stičišče, tokrat predvsem iz gospodarskih razlogov ter na podlagi zasebne pobude. Čezmejna komunikacija je bila močno enostranska: Slovenci iz Slovenije so bili na Koroškem predvsem kupci in vlagatelji denarja, avstrijski državljani pa so prihajali v Slovenijo veliko redkeje. Vendar so opisani procesi pripomogli $\mathrm{k}$ uveljavljanju slovenskega jezika pri pripadnikih slovenske manjšine na avstrijskem Koroškem, pač zaradi uporabnosti v poslovnih stikih. S tem je manjšina dobila pomemben neformalni položaj čezmejnega povezovalca.

Omenjena dinamika gotovo ne bi dosegla tolikšnih razsežnosti, če bi na severni strani Karavank ne bilo slovenske manjšine. Zaradi sprememb v avstrijski družbi je pritisk na manjšino precej popustil. Manjšina je že dosegla podobno družbenogospodarsko sestavo kot večinski narod. Koroški Slovenci so postali prostorsko in družbeno bolj gibljivi. Uveljavili so se tudi $\mathrm{v}$ različnih uslužnostnih dejavnostih in s tem postali pomemben dejavnik razvoja obmejnega območja ter partnerji čezmejnega povezovanja.

V obdobju po osamosvojitvi Slovenije se je pritisk slovenskih kupcev v koroške trgovine, banke in zavarovalnice močno zmanjšal. Trgovina $v$ Sloveniji se je reorganizirala, postala je konkurenčna, ponudba se je izboljšala in za pot preko Karavank je navdušenje precej popustilo, nikakor pa ni prenehalo. Hkrati se je oblikoval nasprotni tok. Avstrijski kupci so zaradi nizkih cen goriva, gostinskih storitev ter nakupovalnih možnosti $\mathrm{v}$ brezcarinskih prodajalnah postali redni gostje bencinskih servisov, trgovin in lokalov $\mathrm{v}$ obmejnem pasu. Vedno pogosteje uporabljajo tudi druge storitve in usluge, kot npr. zdravstvene ter zobozdravstvene. Hkrati je v Sloveniji naraščalo število podružnic avstrijskih trgovskih podjetij, pa tudi zavarovalnic in bank. Nekdanji agentje so postali predstavniki novih poslovalnic. Tudi predstavniki manjšine so bili zlasti pri večjih podjetjih pogosto udeleženi pri teh poslih zaradi poznavanja jezika, prava, navad in mentalitete. Hkrati je pričelo naraščati tudi število podjetnikov z obeh strani meje, ki so pričeli sodelovati med seboj (Zupančič, 1997; Zupančič, 1998). Pojem Karavank kot ločnice je pričel izginjati tako v gospodarskem, kulturnem kakor tudi v psihološkem smislu. Mejo premagujejo tudi izboljšane prometnice. Leta 1991 je bil dograjen avtocestni predor pod Karavankami, modernizirali pa so tudi prehoda čez Ljubelj in Jezersko.

Pomembne premike pri čezmejnem sodelovanju je treba omeniti tudi pri manjšinskem šolstvu na Koroškem. Večja strpnost večine na eni ter nove potrebe po znanju slovenščine na drugi strani so ob uveljavljanju evropskega duha čezmejnega sodelovanja koroškim Slovencem pomagale povečati možnost strokovnega izobraževanja v lastnem jeziku. Poleg slovenske gimnazije, ki je že krepko pognala korenine $\mathrm{v}$ manjšinskem prostoru, sta $\mathrm{v}$ začetku devetdesetih let pričeli delovati še Dvojezična trgovska akademija $\mathrm{v}$ Celovcu in zasebna (cerkvena) Višja šola za gospodarske poklice v Št. Petru pri Št. Jakobu v Rožu. Obe šoli usposabljata kandidate predvsem za področje gospodarskega poslovanja, bančništva, 
zavarovalništva, turizma, trgovine in gostinstva. Značilnost obeh šol je, da jih obiskuje tudi veliko dijakov iz Slovenije (Zupančič, 1998). Šoli dajeta poleg strokovne izobrazbe velik poudarek tudi jezikovni izobrazbi, večkulturni vzgoji ter strpnosti. Kar so danes dijaki, bodo jutri lahko poslovni partnerji.

Podobno kot v primeru Goriške ali Tržaške v Italiji (Bufon, 1995) ima tudi na avstrijskem Koroškem izredno pomembno povezovalno vlogo slovenska manjšina, ki se je pokazala kot najbolj primeren posrednik pri čezmejnm sodelovanju. V različne oblike se pripadniki manjšine vključujejo pretežno iz gospodarskih potreb in koristi, a tudi etničnih, včasih čustveno obarvanih pobud ne gre zanikati. Karavanke so ponovno postale povezovališče Slovencev z obeh strani meje.

Prej naštete oblike čezmejnega sodelovanja so spontan odraz koristi posameznikov in skupin. Prav tako in za bodočnost morda še bolj pomembne pa so nekatere formalne oblike čezmejnega sodelovanja in povezovanja, ki lahko individualne pobude olajša ali sploh vzpodbudi. Že v okviru skupnosti Alpe-Jadran je skupna skrb za naravno dediščino posameznih predelov pripeljala do dogovorov o oblikovanju zaščitenih območij, ki bi segale tudi čez državne meje. V ta okvir sodijo tudi sporazumevanja o možnih skupnih naložbah $\mathrm{v}$ turistično infrastrukturo, od smučišč do gorskih pohodniških poti.

Vključevanje Slovenije v Evropsko zvezo narekuje tudi pospeševanje dejavnosti na področju čezmejnega sodelovanja. Na medregionalni ravni te interese uresničujejo $\mathrm{v}$ okvirih programov INTERREG, katerih osnovna skrb je namenjena pospeševanju čezmejnega sodelovanja regij in manjših upravnih enot. Pomembno težo ima tudi pri urejanju infrastrukture ter analizi učinkov na pokrajino in ljudi. Slovenija pri tem podpira predvsem peti koridor (Sloveniko) in jo tudi pospešeno gradi, medtem ko ima prečna smer, ki poteka čez Karavanke, drugotno vlogo. Vendar utegne imeti prav ta prometna smer (München - Salzburg - Beljak - Karavanke - Ljubljana - Zagreb in dalje proti Balkanu) v prihodnosti še prav vidno vlogo (elaborat: SPIL projekt).

$\mathrm{Za}$ formalne oblike čezmejnega sodelovanja so $\mathrm{v}$ tem oziru na krajevni in regionalni ravni veliko bolj pomembni projekti v okviru PHARE. Partnerji sodelovanja so krajevne in regionalne skupnosti na obeh straneh meje. Sloveniji je ovira, ker sedaj razen med občino in državo nima vmesne upravne enote, ki bi lahko postala partner čezmejnega sodelovanja. Na ravni občin je pobud, pričakovanj ter teženj več, pogosto prehitevajo načrte in težnje širših skupnosti. Pri čezmejnem sodelovanju so dejavne zlasti občine na tromeji, Tržič in Borovlje, Železna Kapla in Jezersko, Železna Kapla in Luče, Črna in Železna Kapla itd. Najpogostejše skupne točke so urejanje prometnih infrastrukture, varovanje okolja in naravne dediščine in razvoj turizma. V letih 1995 do 1997 je na območju Karavank potekalo 12 projektov s sofinanciranjem PHARE v skupni vrednosti 5.239.000 ECU. Skoraj dve tretjini vsote izvirata iz te fundacije. Polovica sredstev je bila namenjena projektom urejanja prometne infrastrukture, $38 \%$ projektom gospodarskega razvoja, $8 \%$ razvoju človeških potencialov (izobraževanje, usposabljanje, agencije ipd.) in $4 \%$ projektom urejanja in varstva okolja (Annual Report 1997). Skupna kandidatura Slovenije, avstrijske Koroške in Furlanije Julijske krajine za zimske olimpijske igre leta 2006 ob tromeji torej ne pomeni 
osamljenega primera čezmejnega povezovanje niti ga ni mogoče obravnavati kot začetek, temveč kvečjemu kot posledico že uveljavljenih čezmejnih odnosov in povezav. Dokaz več, da so Karavanke postale predmet skupnih skrbi in načrtov, torej povezovališče in stičišče.

\section{PRIHODNOST ČEZMEJNEGA SODELOVANJA}

V splošnem gledano je območje Karavank v svoji zgodovini pogosto dajalo videz ločnice, toda skoraj nikoli niso bile neprehodne. Različne vrste stikov so obstajale malodane ves čas. Današnje razmere kažejo na preseženost meje v fizičnem, gospodarskem in kulturnem smislu, saj obstaja vrsta dejavnosti in stikov zlasti na ravni zasebnih koristi ter krajevne pobude, a vedno bolj tudi na ravni regij in držav. Slednje je skladno z evropskim duhom preseganja posledic politične razmejitve in ločevanja v polpreteklem obdobju.

Napredek pri razvoju čezmejnega sodelovanja in povezovanja koristi tako krajevnemu prebivalstvu kot tudi širšemu zaledju, v našem primeru Sloveniji in Koroški (Avstriji) v celoti. Slovenska manjšina na Koroškem ima pri tem še posebej vidno mesto, ker je dovolj številčna in primerno organizirana ter usposobljena za nosilca dejavnosti $\mathrm{V}$ obmejnem območju in pobudnika različnih čezmejnih povezav.

Vendar se postavlja tehtno vprašanje, ali so Karavanke kot ločnica presežene tudi v duhovnem smislu. So mar odpravljeni stari miselni vzorci, predstave in predsodki o prebivalcih to- in onstran meje oziroma glede na njihovo narodno pripadnost, materin jezik in kulturo? Ali niso (žal) še zelo močni stari stereotipi, ki so grenili življenje članom slovenske skupnosti na Koroškem? Žal moramo ugotoviti še precej teh sledov nekdanjega medetničnega nasprotovanja in sporov, čeprav se je neposredni pritisk na slovensko manjšino na Koroškem precej zmanjšal. Vztrajanje pri nasprotovanju ne more biti dober sopotnik čezmejnega sodelovanja in povezovanja, a hkrati je slednje skoraj edino sredstvo, s katerimi je mogoče počasi, a vztrajno odpravljati stare predsodke in spore.

Karavanke so postale stičišče Slovencev z obeh strani meje. Sedaj je priložnost, da postanejo tudi povezovališče drugih narodov, jezikov in kultur. 


\section{LITERATURA}

1. Annual Report 1997. Phare Cross Border Cooperation. Programme Implementation Unit in Slovenia.

2. Barker T. M., 1984: The Slovene Minority in Carinthia. New York, Columbia University Press.

3. Božič B., 1980: Zgodovina Slovencev. Ljubljana, DZS.

4. Bufon M., 1995: Prostor, meje, ljudje. Razvoj prekomejnih odnosov, struktura obmejnega

5. Gradivo SPIL projekta (Slovenska Prometna, Informacijska in Logistična Infrastruktura), Ljubljana, 15. 1. 1998.

6. Klemenčič V., 1990: Metodologija uradnih popisov prebivalstva pripadnikov slovenske manjšine v Italiji, Avstriji in na Madžarskem. Narodne manjšine, SAZU, 31-45.

7. Območja in vrednotenje obmejnosti na Goriškem. Ljubljana. Trst, Znanstveni inštitut FF, SLORI.

8. Podlipnig K., 1991: Die Wirtschaftsbeziehungen zwischen Kärnten und Slowenien- Stand und Perspektiven. Wien, Mitteilungen des Arbeitskreises für Neue Methoden in der Regionalforschung 21, 119-125.

9. Randall R. R., 1955: The Political Geography of the Klagenfurt Plebiscite Area. Worcester, Massachusets.

10. Steinicke E., Zupančič J., 1994: Die Kärntner Slowenen - eine Volksgruppe der Peripherie. Wien, GW Unterricht Nr. 53, 40-56

11. Taylor A. J. P., 1956: Habsburška monarhija 1809 - 1918. Ljubljana, DZS.

12. Wastl -Walter D, Krutner E., 1991: Die Bedeutung des Einkaufstourismus aus Slowenien für Klagenfurt und Südkärnten. Wien, Mitteilungen des Arbeitskreises für Neue Methoden in der Regionalforschung 21, 119-125.

13. Zgodovina Slovencev, 1980: Ljubljana, Cankarjeva založba.

14. Zupančič J., 1992: Vpliv socialnogeografske preobrazbe na položaj slovenske manjšine na avstrijskem Koroškem. Ljubljana, magistrska naloga, Filozofska fakulteta.

15. Zupančič J., 1996: Slovenci v Avstriji. Sodobni socialnogeografski procesi in ohranjanje identitete. Ljubljana, doktorska disertacija, Filozofska fakulteta.

16. Zupančič J., 1997, Slovene border cities along the Slovene - Austrian border - a new geopolitical and spatial situation, Small European Regions During Transition Period, Transformation of Settlement sistems, Opole, 83-90.

17. Zupančič J., 1997: Razsežnosti regionalne identitete na primeru Istre in Koroške. Koper, Annales 10/97, 307-316.

18. Zupančič J., 1997: Slovenia: Transformation and European Integration. The Path Towards European Integration, The Case of Czech Republic, Hungary, Poland, Slovakia, Slovenia, and the Baltic States. Economic Restructuring versus 
Integration Process. Warsawa, European Spatial Research and Policy, Vol. 4, 101-112.

19. Zupančič J., 1998: The Migration of Slovenes to Austria during Transition Period.Opole, Migration Proces in Small European Regions during Transition Period, (v tisku).

20. Zwitter F., Šidak J., Bogdanov V., 1962: Nacionalni problemi v Habsburški monarhiji. Ljubljana, Slovenska matica.

\title{
THE KARAVANKE RANGE - FROM ITS DIVIDING TO THE UNITING ROLE BETWEEN SLOVENIANS ON BOTH SIDES OF THE BORDER
}

\begin{abstract}
Summary
For several centuries, the Karavanke range represented a line of separation between two countries within the frame of a single political and economic system. The Slovenians living on either side of the border were the common and the linking element of two similar regions as to physical features, separated with a natural mountain barrier across which lively exchange went on. It was precisely this physical aspect of the line of separation which, after the collapse of Austro-Hungary and the battle for southern Carinthia, turned to be an argument in favour of political division during the diplomatic sessions, with which the Slovenians in (Austrian) Carinthia got the status of minority in 1920, and thus began a separate economic, social and ethnic development. Differences became even more evident after the $2^{\text {nd }}$ World War when in Slovenia a paradigm of industrial development was put in effect, while in Carinthia the growth of tertiary sector was also put in effect beside the industrialization. Differences between the capitalist and the socialist social systems were also manifested in a closed type of the border in the first decade after the $2^{\text {nd }}$ World War. Later on, the border turned to a passable and open border. In the second half of the eighties, customers from Slovenia flooded shops in Carinthia. After Slovenia had gained independence the transformation of the border across the Karavanke range began through effectuating bidirectional exchange of goods, people, information and capital, so that the border has gradually assumed a uniting role for Slovenians on its either side. The transborder cooperation is in the process of being intensified with common transborder projects that are carried out within the frames of PHARE and INTERREG. A greater degree of cooperation is held back by the Schengen provisions. The Karavanke range as a juncture continues to be a challenge to the present and the future in the following spheres: national parks, transborder transport, economy, culture and information, which is good so for the regional development of Slovenia and Carinthia as for Slovenian minority in Carinthia.
\end{abstract}

